\title{
Vodilne evropske trajnostne soseske: ključna načela in procesi
}

V zadnjih letih je vse več lokalnih projektov trajnostne urbane preobrazbe pogosto definiranih kot trajnostne soseske. Te so opisane kot » poskusi na področju urbanega trajnostnega razvoja «, ki bi lahko dali konkretne odgovore na mnoge izzive, s katerimi se srečujejo današnja mesta oziroma družba. Namen tega članka je raziskati načrtovalski proces in razvoj dveh vodilnih primerov trajnostnih sosesk, pri katerih sta bili uporabljeni različni strategiji začetne implementacije: pristop »od zgoraj navzdol « v soseski Western Harbour (Malmö) in participatorni pristop »od spodaj navzgor« v soseski Vauban (Freiburg).
Cilj članka je proučiti, kako je začetni implementacijski pristop pri trajnostni urbani prenovi vplival na urbanistično načrtovanje, socialno vzdržnost in lokalno upravljanje sosesk. Raziskava se osredotoča tudi na to, kako sta soseski vplivali oziroma prenesli »trajnostne urbane rešitve « $\mathrm{v}$ druge urbane kontekste.

Ključne besede: trajnostne soseske, trajnostni urbani razvoj, principi novega urbanizma, procesi urbanega eksperimentiranja, ekolaboratoriji, Vauban, Western Harbour 


\section{Uvod in ozadje raziskave}

V zadnjem desetletju postajajo vse pogostejše različne skupnostne trajnostne pobude manjšega obsega - običajno majhna mesta, vasi in soseske (Forrest in Wiek, 2014). Lokalni projekti trajnostne urbane preobrazbe $\mathrm{v}$ mestih so pogosto definirani kot trajnostne soseske. Te so lahko celovita rešitev, ki omogoča trajnostno urbano ravnotežje na lokalni ravni (Rudlin in Falk, 2009). David Harvey (1990) opredeljuje trajnostno sosesko kot samostojno urbano območje v mestu, ki ohranja simbolno bogastvo tradicionalne urbane oblike ter hkrati temelji na dialogu in raznolikosti. Oblikovanje trajnostnih sosesk in razvoj lokalnih urbanih skupnosti zahtevata določitev jasnih okoljskih, socialnih in ekonomskih ciljev, ki so idealno v konstantnem ravnotežju (Churchill in Baetz, 1999). Harriet Bulkeley idr. (2015) trdijo, da je nabor posegov, ki oblikujejo poseben okvir urbanega upravljanja podnebnih sprememb ter pri tem razvijajo, preskušajo in potrjujejo izkušnje odzivanja na podnebne spremembe, pogosto eksperimentalne narave. Trajnostne soseske lahko razumemo kot eksperimente ali žive laboratorije (ang. living labs), ki ponujajo konkretne odgovore na številne izzive, $s$ katerimi se srečujejo mesta in družba. Lahko bi postale nov aktivni urbani model, ki deluje skladno $s$ sodobnimi principi trajnostnega razvoja in pooseblja alternativne rešitve za netrajnostne prakse $\mathrm{v}$ sodobnih mestih.

S poglobljenim pregledom literature je bilo ugotovljeno, da se je večina trajnostnih sosesk razvila v Severni in Zahodni Evropi (Medved, 2016). Zato Stella Kyvelou, Maria Sinou, Isabelle Baer in Toni Papadopoulos (2012) menijo, da je koncept trajnostne soseske severnoevropski model. Čeprav imajo tudi južnoevropske trajnostne soseske velik potencial, so le redko navedene kot primeri dobrih praks. Te trajnostne soseske niso pogosto proučevane v literaturi, ki se nanaša na urbani trajnostni razvoj. Velikokrat pa so skupaj proučevani ali navajani primeri dobre prakse trajnostnih sosesk iz Severne in Zahodne Evrope. V obsežnem pregledu literature (Medved, 2016) so bili najpogosteje prepoznani in s tem citirani vodilni primeri trajnostnih sosesk v teh mestih: Culemborg - Nizozemska (EVA-Lanxmeer), Utrecht -Nizozemska (Leidsche Rijn), Amsterdam - Nizozemska (GWL Terrein), Malmö Švedska (Western Harbour in Augustenborg), Stockholm Švedska (Hammarby Sjöstad), Freiburg - Nemčija (Vauban, Rieselfeld in Weingarten), Hannover - Nemčija (Kronsberg), Ostfildern - Nemčija (Scharnhauser Park), Tübingen - Nemčija (Französisches Viertel-Südstadt), Helsinki - Finska (Viikki), København - Danska (Vasterbo), Sutton - Velika Britanija (BedZed), London - Velika Britanija (Greenwich Millenium Village) in Linz - Avstrija (SolarCity). Med omenjenimi primeri dobre prakse so velike razlike, zlasti z vidika vprašanj, povezanih s socialno vzdržnostjo in upravljanjem lo- kalne skupnosti. Večina priznanih trajnostnih sosesk je izkazala visoko stopnjo odličnosti glede okoljskih vidikov trajnostnega razvoja, vendar se zdi, da se socialna vzdržnost in sistem lokalnega upravljanja v nekaterih vodilnih trajnostnih soseskah nista razvijala sistematično.

\section{Raziskovalni cilji}

Navedemo lahko dve okoliščini, ki sta vplivali na oblikovanje hipotez in raziskovalnih ciljev v članku. Prvič, avtor je v predhodni analizi urbanih skupnosti ugotovil potencialno povezavo oziroma korelacijo med močno povezano urbano skupnostjo, lokalnim upravljanjem in začetnim pristopom implementacije pri urbanističnem načrtovanju. To posebno povezavo je poudarilo tudi več raziskovalcev urbanega razvoja. Hugh Barton, Marcus Grant in Richard Guise (2003) denimo trdijo, da bolj ko je lokalna skupnost vključena v načrtovanje in razvoj soseske, večja je verjetnost razvoja lokalnega urbanega prostora, ki ima določen pomen za skupnost. Hildebrand Frey (1999) je ugotovil, da so ljudje v soseski odgovornejši in med seboj povezani, če so bili vključeni v oblikovanje soseske. Ugotovlja se, da participatorno urbanistično načrtovanje, podprto z delavnicami, forumi ali natečaji, povečuje občutek pripadnosti lokalne urbane skupnosti in njene zavezanosti trajnostnemu urbanemu projektu (Bayulken in Huisingh, 2015). Krepitev sodelovanja pri lokalnem upravljanju je odvisna od neposrednega sodelovanja lokalnih prebivalcev pri sprejemanju odločitev. Lokalno upravljanje zahteva večjo udeležbo civilne družbe, ki tradicionalno tvori jedro javne sfere (Gaventa in Valderrama, 1999).

Avtor je na podlagi navedenih teoretičnih predpostavk oblikoval dve raziskovalni hipotezi:

1. trajnostne soseske, implementirane s participativnim pristopom od spodaj navzgor, so razvile urbane forme, bolj prilagojene lokalni skupnosti v primerjavi s trajnostnimi soseskami, nastalimi s pristopom od zgoraj navzdol;

2. trajnostne soseske, implementirane $s$ participativnim pristopom od spodaj navzgor, so razvile bolj socialno vzdržne lokalne skupnosti in kompleksnejše sisteme lokalnega urbanega upravljanja $\mathrm{v}$ primerjavi s trajnostnimi soseskami, nastalimi s pristopom od zgoraj navzdol.

Za namen analize teh povezav in potrditve obeh hipotez sta bili izbrani dve vodilni trajnostni soseski, ki sta imeli različna začetna pristopa: Vauban (Freiburg, Nemčija) in Western Harbour (Malmö, Švedska) - več v 3. poglavju Raziskovalni pristop in metodologija. Prvi cilj članka je raziskati in analizirati trajnostni soseski z inovativnimi metodološkimi orodji in proučiti, ali (in kako) je začetni pristop implementacije vplival na urbano načrtovanje oziroma urbano formo (hipoteza 1), na 
socialno vzdržnost in zlasti na vključenost skupnosti v vsakdanje odločanje oziroma na lokalno upravljanje obeh sosesk (hipoteza 2).

Druga okoliščna, ki določa raziskovalni fokus članka, je povezana $s$ trditvijo, da je zaradi trenutne hitro naraščajoče stopnje urbanizacije zelo pomembno kolektivno ukrepanje $\mathrm{z}$ udeležbo od spodaj navzgor, ki vključuje tudi zavezo institucij $\mathrm{k}$ uvajanju demonstrativnih trajnostnih urbanih projektov. $\mathrm{Ti}$ bi sčasoma postali prevladujoči primeri urbanega bivanja in način za širjenje svojih trajnostnih urbanih inovacij (Bayulken in Huisingh, 2015). Glede na to, je drugi raziskovalni cilj članka opredeliti, ali (in kako) sta obe soseski že vplivali in širili svoje »trajnostne urbane rešitve « $\mathrm{v}$ drugih urbanih sredinah. Avtorja zanima, ali obstaja razlika, ki se navezuje na »prenos znanja « med obema soseskama, nastalima z različnima implementacijama.

\section{Raziskovalni pristop in metodologija}

Avtor je za primerjalno analizo izbral dve študiji primerov s seznama » primerov dobrih praks trajnostnih sosesk «, omenjenega v uvodu (Bächtold, 2013; Fraker, 2013; Medved, 2016): 1. Vauban (Freiburg, Nemčija), ena najbolj znanih trajnostnih sosesk, nastalih na podlagi pristopa od spodaj navzgor, in 2. Western Harbour (Malmö, Švedska), ena najbolj tipičnih trajnostnih sosesk, nastalih na podlagi pristopa od zgoraj navzdol. Soseski sta prototipa, kako lahko načrtujemo in razvijemo trajnostno sosesko $s$ pristopoma od zgoraj navzdol in od spodaj navzgor (Bächtold, 2013; Fraker, 2013). Gre za dve skrajnosti oziroma dva nasprotna pola strategij implementacije urbanega razvoja. »Atipični ali skrajni primeri pogosto razkrijejo več informacij, saj aktivirajo več akterjev in več osnovnih mehanizmov v preučenih situacijah.« (Flyvbjerg, 2006: 229) Gotovo iz analize, ki temelji le na dveh študijah primerov, ne more izhajati » univerzalna « ugotovitev, lahko pa analiza odpre nova vprašanja oziroma nove vidike za nadaljnje analize in razprave.

Za potrditev prve hipoteze temelji raziskovalni pristop za primerjalno analizo dveh trajnostnih sosesk na analitičnem okviru - » principi novega urbanizma « (CNU in HUD, 2000; Grant, 2006; Rahnama idr., 2012; internet 1). Za potrditev druge hipoteze pa je avtor izbral analitični okvir - »procesi urbanega eksperimentiranja « (Bulkeley idr., 2015). Analitični okvir principov novega urbanizma je izbral, ker je »novi urbanizem « eno glavnih urbanističnih gibanj, ki raziskujejo, kako ustvariti gosto naseljene urbane predele po merilih človeka. Novi urbanizem spodbuja uporabo raznovrstnih elementov urbanega načrtovanja, ki jih je treba prilagoditi lokalnim potrebam (ne nasprotno). Poziva $\mathrm{k}$ vračanju $\mathrm{k}$ urbanizmu po človeški meri, z ulicami, prilagojenimi pešcem, kjer ne prevladujejo avtomobili, ter s prostori z mešano (trgovsko in bivalno) namembnostjo in veliko gostoto gradnje, ki omogočajo živahno mestno življenje (Kushner, 2002). Analitični okvir novega urbanizma združuje večino parametrov in ključnih osnovnih elementov teoretičnega koncepta »kompaktnega mesta « (Rogatka in Ramos Ribeiro, 2015). Z analizo principov novega urbanizma bo možno odgovoriti na prvo hipotezo in potrditi, da so trajnostne soseske, implementirane s participativnim pristopom od spodaj navzgor, razvile bolj lokalni skupnosti prilagojeno urbano formo v primerjavi s trajnostnimi soseskami, nastalimi na podlagi pristopa od zgoraj navzdol. $\mathrm{Na}$ začetku primerjalne analize avtor prouči temeljne značilnosti oziroma funkcije urbanega načrtovanja sosesk Western Harbour in Vauban. Po predstavitvi obeh sosesk $s$ kontrolnim seznamom (preglednica 1), ugotavlja, ali sta trajnostni soseski ustvarili urbane funkcije, skladne z načeli novega urbanizma. Definicije desetih načel novega urbanizma, poudarjene $\mathrm{v}$ drugem stolpcu preglednice 1 (4. poglavje), pomenijo ključne primerjalne elemente analize. $S$ takšnim postopkom primerjave je mogoče razumeti temeljne značilnosti obravnavanih trajnostnih sosesk in določiti, koliko je razvoj sosesk blizu idealom » novega urbanizma «. Analiza poudarja » fizično okolje« oziroma urbanistično formo sosesk in dosežene trajnostne cilje, ki se nanašajo na urbanistično oblikovanje in trajnostni promet.

Za preveritev druge hipoteze je avtor izbral analitični okvir »procesov urbanega eksperimentiranja «, ker so ti zapostavljeni pri večini analiz, ki raziskujejo mesta, in ker analitični okvir procesov dodaja pomembno perspektivo $\mathrm{k}$ razumevanju dinamičnih odnosov med različnimi deležniki skozi čas. Nuno Ferreira da Cruz in Rui Cunha Marques (2014) sta ugotovila, da družbeni, gospodarski in okoljski vidiki niso dovolj za presojo uspešnosti lokalne oblasti. Treba bi jih bilo evalvirati tudi glede vodenja in upravljanja. Zato je treba vključiti analizo lokalnega upravljanja, ki se nanaša na ravnanje institucij, upravljanje ter razmerje med državo (občinami), državljani in drugimi deležniki (Ferreira da Cruz in Marques, 2014). Lokalno upravljanje na ravni soseske je izpostavljeno $\mathrm{z}$ analitičnim okvirom $\gg$ procesov $\ll$. S proučitvijo analitičnega okvira $\gg$ procesov « (Bulkeley idr., 2015) bo mogoče odgovoriti na drugo hipotezo in potrditi, da so trajnostne soseske implementirane $s$ participativnim pristopom od spodaj navzgor razvile socialno vzdržnejšs lokalne skupnosti in kompleksnejše sisteme lokalnega urbanega upravljanja v primerjavi s trajnostnimi soseskami, nastalimi s pristopom od zgoraj navzdol. Pri analitičnem okviru procesov se analiza osredotoča na te faze: ustvarjanje (ang. making), vzdrževanje (ang. maintaing), bivanje (ang. living) in razširjanje informacij (ang. disseminating). Pojem teoretični okvir procesov so uvedli Bulkeley idr. (2015). Procesi » ustvarjanje «, »vzdrževanje« in »bivanje« so zanje ključni vidiki 
urbanega eksperimentiranja. »Razširjanje informacij « je po avtorju dodatni inovativni proces, namenjen ugotavljanju, kako trajnostne soseske med razvijanjem in razširjanjem inovativnih trajnostnih rešitev vplivajo na druga urbana območja oziroma druge soseske po svetu. $\mathrm{Z}$ aplikacijo inovativnega procesa »razširjanje informacij « bo mogoče izvesti drugi del raziskave in ugotoviti, ali izhodiščni pristop implementacije vpliva na prenos » trajnostno urbanih rešitev « v druga urbana območja. V 5. poglavju bosta trajnostni soseski primerjani na osnovi omenjenih štirih $(3+1)$ procesov (definicija procesov $v$ preglednici 2). Analiza » procesov « bo omogočila inovativen vpogled $\mathrm{v}$ dinamično formacijo sistema lokalnega upravljanja skozi čas. Tako bo mogoče razumeti, kako (in če) začetni pristop implementacije (ustvarjanje) v izbranih študijah primerov vpliva na socialno vzdržnost in lokalno upravljanje v nadaljnjih procesih (vzdrževanje, bivanje, razširjanje informacij) oziroma ju določa.

Metodologija zbiranja empiričnih podatkov za analizo vključuje intervjuje s ključnimi deležniki, obiske (terensko delo) sosesk Vauban in Western Harbour ter pregled in analizo znanstvene literature. Avtor je obiskal obe trajnostni soseski ter zbral avdio in grafično gradivo. Aprila 2013 je obiskal sosesko Vauban (Freiburg) in tam dva tedna tudi bival. Od marca do maja 2014 pa je devetkrat obiskal sosesko Western Harbour (Malmö). Intervjuval je glavne mestne urbaniste, urbane razvijalce, predstavnike občin in lokalne skupnosti. Želel je razumeti vlogo vseh sodelujočih deležnikov pri razvoju trajnostnih sosesk. Intervjuji so se osredotočali predvsem na predstavnike občin, ki so neposredno sodelovali pri razvoju urbanih projektov. V zvezi s trajnostno sosesko Vauban je bilo mogoče intervjuvati tudi lokalne mnenjske voditelje skupnosti in predstavnike lokalnih združenj. Ker v soseski Western Harbor ni skupnostnih centrov in združenj ali društev lokalne skupnosti, ni bilo mogoče intervjuvati predstavnikov lokalne skupnosti. V soseski Vauban je avtor intervjuval te predstavnike: Wulf Daseking (mestni urbanist občine Freiburg, ki je načrtoval to trajnostno sosesko), Andreas Delleske (vodja iniciative lokalne skupnosti Forum Vauban) in Sigrid Gombert (nekdanja urednica lokalnega časopisa Vauban Actuel). V soseski Western Harbor je intervjuval te predstavnike: Eva Dalman (nekdanja vodja urbanega projekta Bo01), Maria Lööf (svetovalka oddelka za varstvo okolja občine Malmö) in Jan Johansson (svetovalec na nepremičninskem oddelku občine Malmö). Intervjuji so temeljili na enakem strukturiranem vprašalniku odprtega tipa. Vprašanja so se tematsko navezovala na dejavnike in parametre trajnostnega urbanega načrtovanja, predstavljene $\mathrm{v} \gg$ strukturnem modelu avtonomnih trajnostnih sosesk « (Medved, 2016). Fokus vprašanj se je nanašal na štiri glavne teme: upravljanje naravnih virov, trajnostni promet, socialno-ekonomsko ravnovesje in trajnostno urbanistično načrtovanje. Poseben poudarek v intervjujih se je nanašal tudi na lokalno upravljanje, implementacijski pristop oblikovanja trajnostnih sosesk, vloge, razmerja in pogajalske moči deležnikov, sodelovanje lokalne skupnosti pri načrtovanju itd.

\section{Načela novega urbanizma}

$\mathrm{V}$ tem poglavju so predstavljene temeljne značilnosti obravnavanih trajnostnih sosesk, s posebnim poudarkom na elementih oziroma ciljih trajnostnega oblikovanja, ki se nanašajo na načela »novega urbanizma «. Na koncu poglavja avtor ugotavlja, koliko so ti dosežki oziroma značilnosti trajnostnega urbanega načrtovanja posamične trajnostne soseske $\mathrm{v}$ skladu $\mathrm{z}$ desetimi načli novega urbanizma (preglednica 1). Cilj poglavja je preveriti, ali so urbane forme analiziranih sosesk zgrajene trajnostno $\mathrm{z}$ vidika »novega urbanizma «.

Soseska Vauban (Freiburg) je soseska ob vznožju predela Črni gozd s 5.000 prebivalci in ponuja 700 delovnih mest (Fraker, 2013). Zgrajena je na 42 ha velikem območju nekdanjega francoskega vojaškega oporišča. Pristop od spodaj navzgor je omogočil bodočim prebivalcev, da so z uveljavljenimi investitorji načrtovali in gradili domove na dodeljenih zemljiščih. Tako so ustvarili arhitekturno neuniformirano, nestandardizirano in slikovito sosesko (Field, 2011).

$\mathrm{Z}$ vidika rabe trajnostne energije in upravljanja naravnih virov je soseska Vauban primer učinkovitega nizkoenergijkega urbanega območja in tudi eksperimentalno območje za inovacije. Na robu soseske so zgradili lokalni obrat za daljinsko ogrevanje (CHP), ki kot energente pretežno uporablja sekance iz bližnjega gozda ( $80 \%)$ in delno zemeljski plin $(20 \%)$. Več kot $65 \%$ porabljene električne energije v soseski se ustvari s fotovoltaičnimi paneli, ki so v lasti lokalnih prebivalcev, združenih v »zadrugah sončne energije « (Sperling, 2002). Za poslovne in stanovanjske zgradbe je obvezen standard majhne porabe energije $\left(65 \mathrm{kWh} / \mathrm{m}^{2}\right)$. Lokalni deležniki so aktivno promovirali uporabo dodatnih zelenih tehnologij v zgradbah. Soseska je tako postala eksperimentalno območje za inovativne rešitve, namenjene zmanjševanju porabe naravnih virov in povečanju recikliranja. $\mathrm{V}$ eksperimentalnem bivanjskem laboratoriju (nem. Passivbaus Wobnen und Arbeiten) so denimo testirali in prevzeli inovativne zelene tehnologije, kot so vakuumski sistemi stranišč in manjše bioplinarne, namenjene gospodinjstvom (internet 3; Delleske, 2013).

Koncept trajnostnega prometa v soseski Vauban določa vizija »življenje brez avtomobila«, ki spodbuja alternativne oblike mobilnosti, kot so uporaba koles, souporaba avtomobilov (ang. car-sharing) in učinkovit javni prevoz (Sperling, 2002). Soseska je integrirana v mestno mrežo javnega prevoza. Povezana je z mestnimi avtobusnimi linijami in tramvajem (slika 1c). Lokalni urbani načrt skoraj prepoveduje parkiranje. Ceste so 

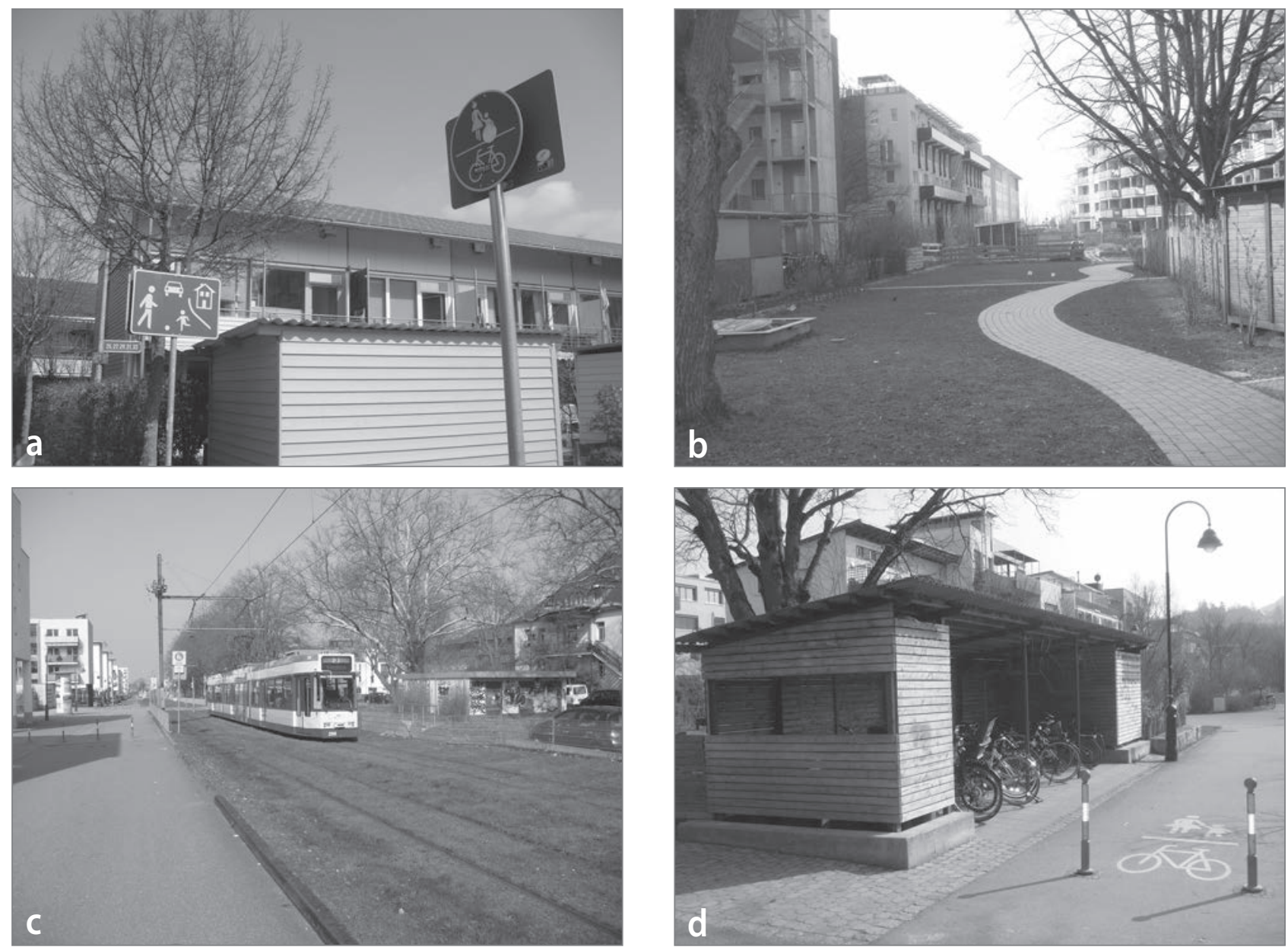

Slika 1: Trajnostni promet in ceste brez avtomobilov v trajnostni soseski Vauban: (a) ceste kot igrišča, (b) ceste brez avtomobilov, (c) tramvaj, (d) kolesarnica (foto: Primož Medved)

prilagojene pešcem in kolesarjem (sliki 1a in 1d). Prometna ureditev spodbuja souporabo avtomobilov. Zaradi teh ukrepov, zakonov, lokalne politike in osveščenosti domačinov glede varovanja okolja ima malo ljudi lastno vozilo. Na 1.000 prebivalcev je le 150 lastnikov avtomobilov. V občini Freiburg je na 1.000 prebivalcev 427 lastnikov avtomobilov - nemško povprečje je 517 (Sperling, 2008; The World Bank, 2013).

Z vidika urbanističnega načrtovanja je soseski uspelo uresničiti začetno vizijo »graditi gosto, a zeleno«, z velikim številom parkov, dreves in odprtih zelenih javnih površin (sliki $2 \mathrm{~b}$ in 2d). Gostota naseljenosti v soseski Vauban (št. ljudi/ha) je 122, v mestu Freiburg pa 15 (Foletta, 2011; Banister, 2005). Urbanistični načrti so bili usmerjeni $\mathrm{k}$ ustvarjanju bivalnega prostora, kjer ni potrebe po avtomobilu in je vse na dosegu rok kot v srednjeveških mestih (Daseking, 2013). Stavbe imajo večinoma tri do štiri nadstropja. Prostori v pritličju so namenjeni storitvenim dejavnostim in zadovoljujejo osnovne življenjske potrebe prebivalcev soseske.

V zvezi z javnimi prostori je civilnemu združenju Forum Vauban uspelo ustvariti obsežen javni prostor » Haus $037 \ll$.
Nastal je s prestrukturiranjem nekdanje francoske vojašnice (slika 2a). Gre za sodobni večnamenski objekt, heterogen javni prostor, ki vključuje restavracijo, »pub «, prostore za sestanke in srečanja, pisarne in »hostel « (Fraker, 2013). Takšen javni prostor krepi lokalno identiteto soseske in zagotavlja njenim prebivalcem prostor, kjer se lahko srečujejo in družijo. Drug pomemben javni prostor, ki je pred objektom Haus 037, pa je osrednji trg (plaza) Alfred-Döblin-Platz. To je srce družbenega življenja v soseski Vauban. Na njem je tržnica biološko pridelane hrane (dvakrat na teden) in izmenjevalna tržnica (enkrat na mesec). Pristop $\mathrm{k}$ javnim urbanim prostorom, razvit $\mathrm{v}$ soseski Vauban, potrjuje ugotovitve Nataše Bratina Jurkovič (2014), ki meni, da se tveganje za neustrezno načrtovanje zmanjša, če pri načrtih urbane prenove sodelujejo prebivalci soseske.

Soseska Western Harbour (Malmö) je skupaj s sosesko Hammarby Sjöstad (Stockholm) najbolj reprezentativni švedski primer trajnostne soseske. Na območju soseske Western Harbour so bili prej pristanišče, industrijski predel in ladjedelnica Kockums. Urbana preobrazba se je začela z zaprtjem tovarne Saab leta 1990. To je sprostilo 140 ha privlačnih zazidljivih površin $\mathrm{v}$ bližini središča mesta in neposredno ob morju. Ob- 

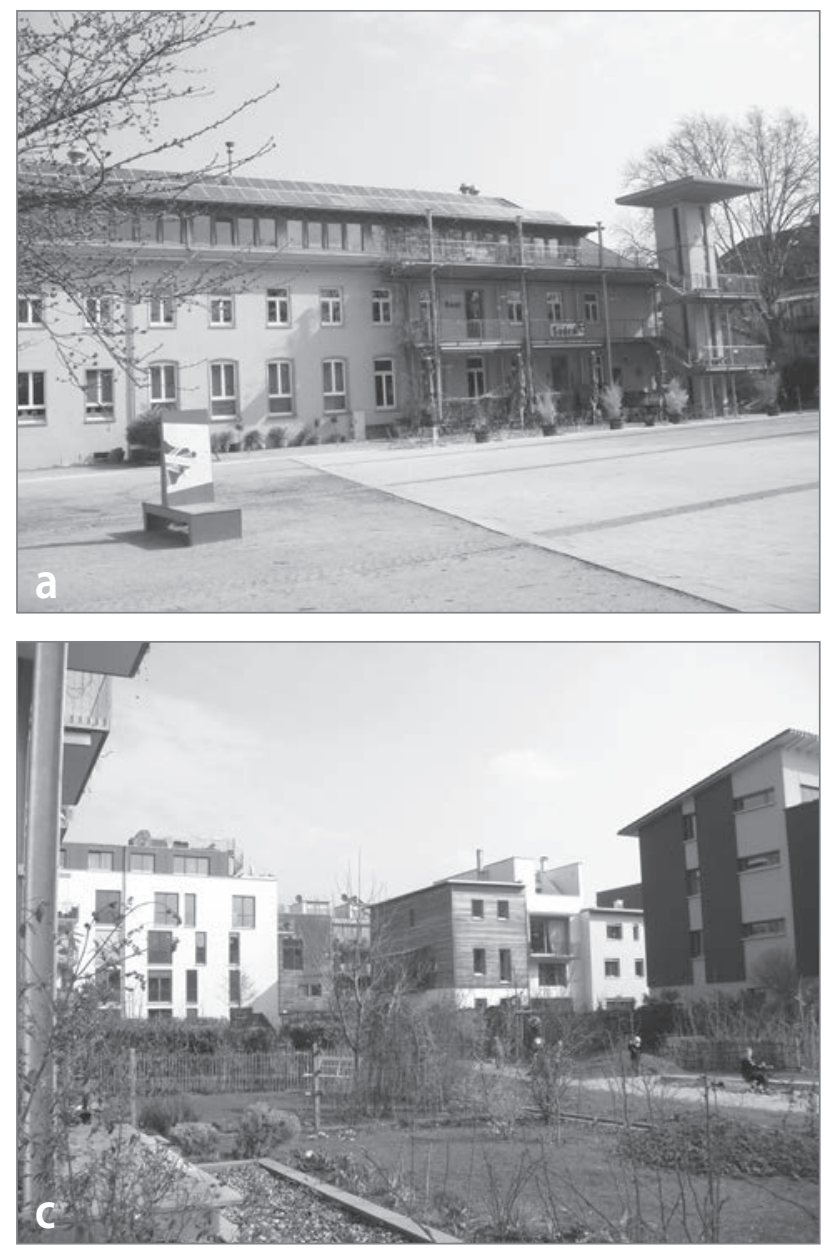
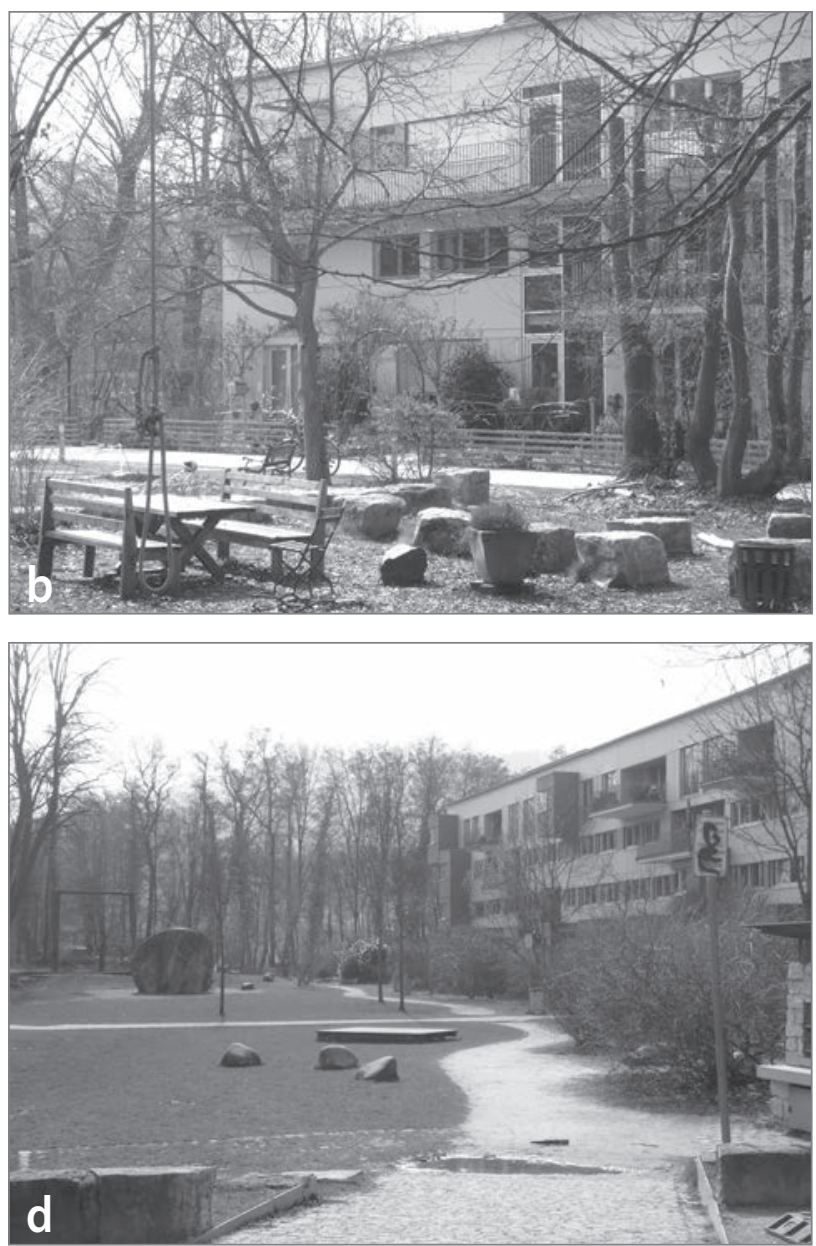

d

Slika 2: Odprti javni prostori trajnostne soseske Vauban: (a) Haus 037 in trg Alfred-Döblin Platz, (b) park, (c) urbani vrt, (d) park (foto: Primož Medved)

močje se je razvilo v sodobno sosesko z velikimi trajnostnimi ambicijami. Soseska Western Harbour je bil zgrajena postopoma, v treh fazah: Bo01, Flagghusen-Bo02, Fullriggaren-Bo03. Nova trajnostna bivalna območja se še vedno gradijo. Trenutno ima soseska 4.300 prebivalcev. V njej je zaposlenih kar 9.000 oseb (Foletta, 2011). Število delovnih mest na prebivalca je zelo visoko, če ga primerjamo s podobnimi trajnostnimi soseskami v Evropi. Ko bo soseska končana, bo v njej delalo in študiralo 30.000 oseb. Western Harbour postaja novo študentsko in gospodarsko središče mesta Malmö.

$\mathrm{Z}$ vidika rabe trajnostne energije in upravljanja naravnih virov je prvo trajnostno grajeno urbano območje $\mathrm{v}$ okviru soseske Western Harbour soseska Bo01, prva trajnostna soseska na svetu, stoodstotno oskrbovana z obnovljivimi viri energije (Bächtold, 2013). Električna energija nastaja iz sončne in vetrne energije. Vir ogrevanja sta geotermalna energija podzemne vode $(80 \%)$ in delno sončna energija $(15 \%)$. Soseska Western Harbour pooseblja vir zelenih inovacij tudi na področjih, ki niso povezana neposredno $\mathrm{z}$ energijo, to sta zlasti upravljanje voda in ravnanje $\mathrm{z}$ odpadki. $\mathrm{V}$ nekaterih zgradbah (recimo v osnovni šoli) uporabljajo deževnico za pranje perila, zalivanje vrtov in izplakovanje stranišč. Gospodinjski odpadki se pre- oblikujejo v nov vir energije $\mathrm{z}$ visokotehnološko predelavo odpadkov z vakuumskimi cevmi, iz organskih odpadkov nastaja bioplin, ravne strehe objektov pa so običajno zasajene z rastlinami (Bächtold, 2013).

Podobno kot v soseski Vauban se trajnostna prometna strategija v soseski Western Harbour osredotoča na zmanjševanje odvisnosti od avtomobilov. Leta 2011 so ugotovili, da je delež lastnikov avtomobilov v soseski Western Harbour razmeroma visok - 440 avtomobilov na 1.000 prebivalcev in le malo nižji od povprečja v mestu Malmö - 480 avtomobilov na 1.000 prebivalcev (Foletta, 2011). V soseski Western Harbour so avtomobili sicer dovoljeni na nekaterih ulicah, toda trajnostna soseska skuša s svojo specifično zgoščeno urbano formo spodbujati hojo in kolesarjenje (Bächtold, 2013). Veliko truda je bilo vloženega v sistem kolesarskih stez in izboljšavo pločnikov za pešce (sliki $3 \mathrm{c}$ in $3 \mathrm{~d}$ ). Lahek dostop do soseske iz drugih delov mesta Malmö zagotavlja tudi učinkovit sistem avtobusov na bioplin, elektriko ali zemeljski plin. Parkirišča za avtomobile zagotovljajo podzemne garaže, delno pa parkirna mesta na ulicah. Razvojniki so v začetni fazi predlagali 0,7 parkirnega prostora/stanovanje. $S$ tem so želeli spodbuditi hojo, kolesarjenje in uporabo javnega prevoza (Fraker, 2013; Zinkernagel, 

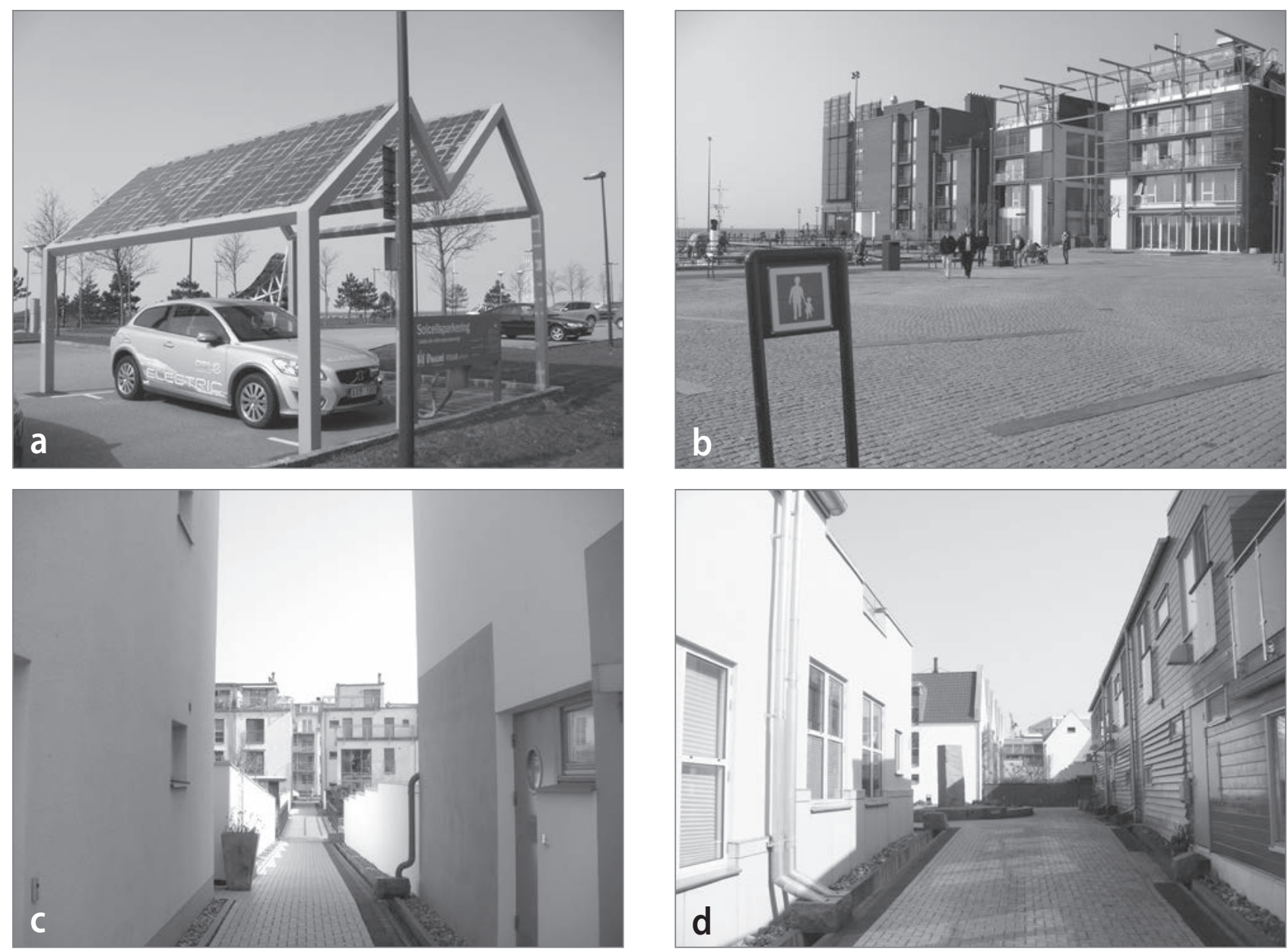

Slika 3: Trajnostni promet in ceste brez avtomobilov v trajnostni soseski Western Harbour: (a) električni avtomobil v okviru storitve souporaba avtomobila, (b) javni prostor brez avtomobilov, (c) in (d) ulice brez avtomobilov (foto: Primož Medved)

2014). Vendar so zaradi pritiska lokalnih prebivalcev spremenili parkirno politiko in povišali število parkirnih mest $(1,5$ parkirnega mesta/stanovanje). Prebivalci soseske lahko uporabijo storitev souporaba avtomobila (slika 3a), ki je v soseski postala zelo razširjena (Johansson, 2014; Lööf, 2014). Pri razvoju soseske Fullriggaren-Bo03 pa je bilo članstvo v shemo souporabe avtomobilov vključeno v najemnino za prvi dve leti. Zadnje leto je v soseski Western Harbour postala razširjena celo souporaba koles.

Soseska Western Harbour se z arhitekturnega vidika zgleduje po urbanističnem načrtovanju 19. stoletja, ko je bila gostota naseljenosti razmeroma velika. Gostota naseljenosti prebivalstva (št. oseb/ha) v soseski Western Harbour je 57, v mestu Malmö pa 19 (Foletta, 2011). Večnamenske zgradbe s pogledom na glavno ulico imajo bivalne, storitvene in poslovne funkcije. $\mathrm{Ob}$ morju so visoke šestnadstropne stavbe, ki so nekakšna vetrna zaščita notranjim nižjjim stavbam. V obeh soseskah je urbana forma zelo heterogena. Urbano območje oziroma mini sosesko Bo01 v okviru soseske Western Harbour, ki ima 1.900 stanovanj, je načrtovalo 10 razvojnikov in 20 arhitektov (Bächtold,
2013: 94). Trajnostna soseska Western Harbour je prilagojena potrebam pešcev $s$ številnimi med seboj povezanimi ulicami in veliko zelenimi površinami, parkom za skejtanje (slika 4c), obsežnimi odprtimi vodnimi kanali, bazeni in fontanami (sliki $4 \mathrm{a}$ in $4 \mathrm{~d})$.

Ozek pas ob morju v soseski Western Harbor je bil preurejen $\mathrm{v}$ priljubljeno javno sprehajališč za domačine in zunanje obiskovalce, imenovano »Sundspromenaden « - slika $4 \mathrm{~b}$ (Foletta, 2011). Promenada uteleša »družbeno « funkcijo osrednjega družabnega prostora soseske, podobno kot trg Alfred-DöblinPlatz v soseski Vauban. V nasprotju s slednjo pa v soseski Western Harbour ni objekta, namenjenega srečanjem in druženju lokalnega prebivalstva.

Gibanje novega urbanizma še posebej promovira urbanistično raznolikost in heterogenost družbene strukture v urbanem okolju. Z vidika urbanega načrtovanja - » raznovrstne tipologije stavb « - sta obe soseski dosegli visoko raven raznolikosti stavb in javnih prostorov (promenade, trgi, urbani vrtovi, park za skejtanje itd.). Z vidika heterogenosti prebivalcev pa obema 

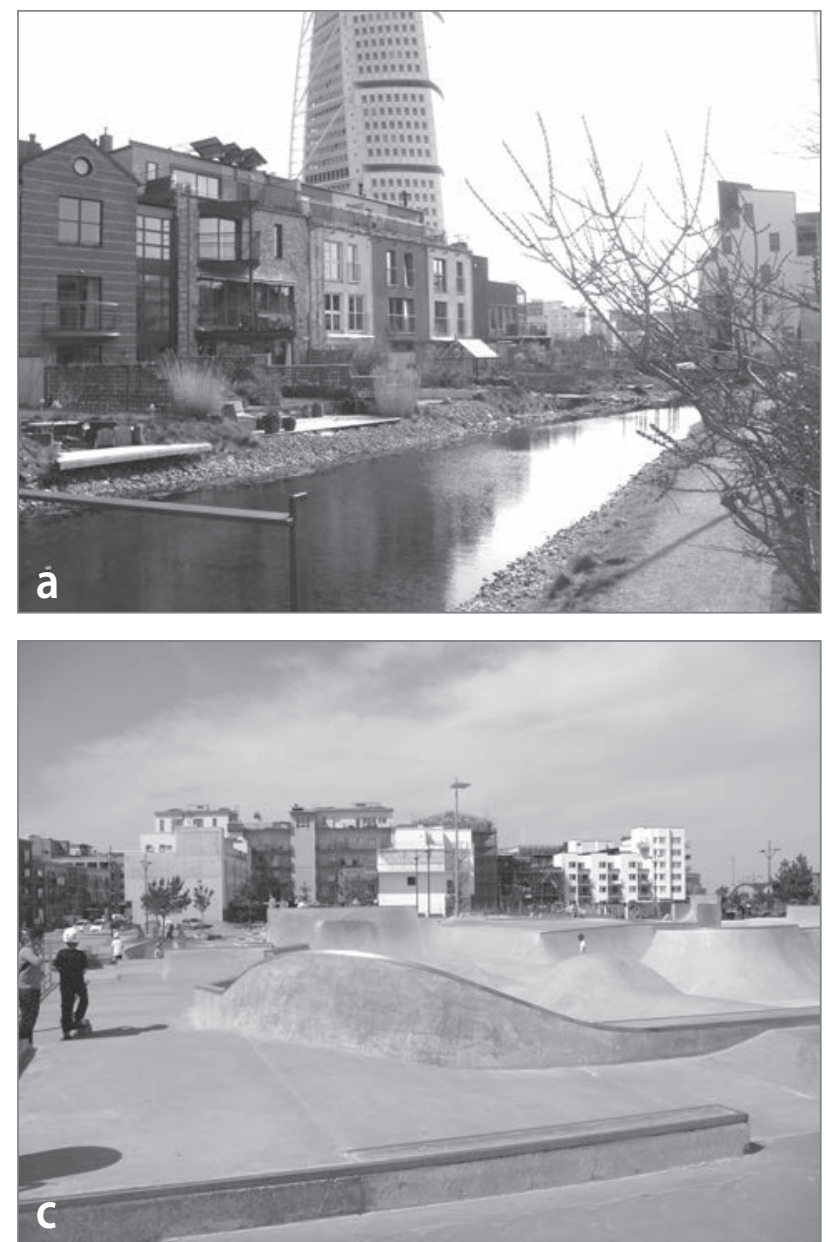
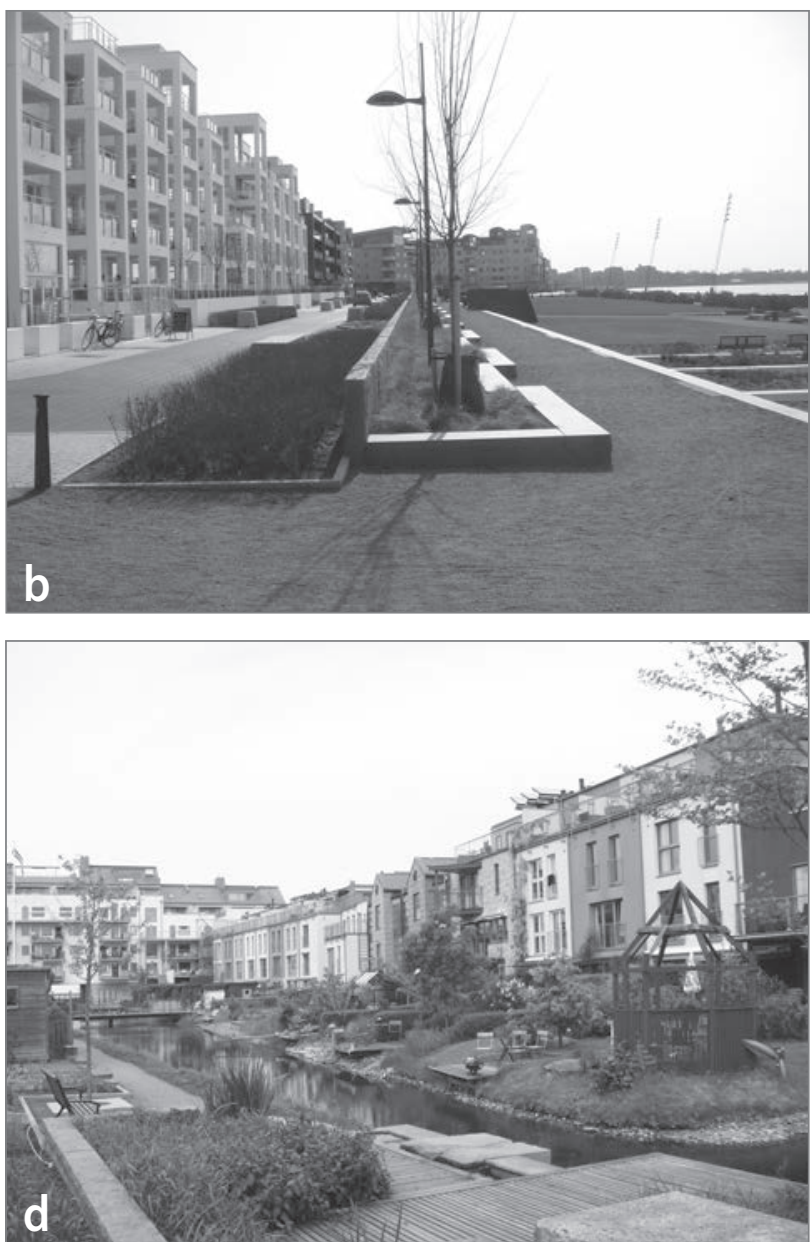

d

Slika 4: Odprti javni prostori v trajnostni soseski Western Harbour: (a) vodni kanal, (b) javna promenada »Sundspromenaden«, (c) park za skejtanje, (d) park (foto: Primož Medved)

soseskama ni uspelo doseči (ali ohraniti) heterogene družbene strukture. Poleg tega obstaja realna možnost, da bi lahko trajnostni soseski postali »ekskluzivni citadeli«(Fainstein, 2010). Soseski Vauban je še posebej v prvih letih uspelo zagotoviti precejšen delež cenovno dostopnih stanovanj (Fraker, 2013). $\mathrm{V}$ zadnjem času pa so se najemnine zelo povišale. Stanovanja so zdaj med najdražjimi v mestu Freiburg, zato je večina prebivalcev izobraženih strokovnjakov (Bächtold, 2013:81). Tudi Sigrid Gombert (2013) in Carsten Sperling (2008) ugotavljata spremembo družbene strukture (od prvotnih skupin aktivistov do mladih družin iz višjega srednjega razreda), vendar se je prvotna urbana družbena struktura delno ohranila (»socialna stanovanja « SUSI, Haus 037 itd.). Tudi soseska Western Harbour je bila prvotno mišljena kot heterogeno in socialno vzdržno urbano območje (Kärrholm, 2011), zdaj pa v njej pretežno prebiva zgornji srednji razred. Prvi trajnostni urbani del (Bo01) je bil očitno namenjen družinam z višjimi dohodki (Madureira, 2015).

Izhajajoč iz predstavitve značilnosti (urbanega načrtovanja) trajnostnih sosesk, je mogoče trditi, da obe soseski izpolnjujeta večino temeljnih zahtev, vključenih $\mathrm{v}$ posamezna načela novega urbanizma (preglednica 1). Ugotovljeno je bilo, da se edina zahteva ( $v$ okviru tretjega načela novega urbanizma » večnamenska raba in raznolikost «), ki ni bila dosežena pri obeh soseskah, nanaša na »raznolikost prebivalcev - glede starosti, dohodkov, kulture in rase«. Soseska Western Harbour ni popolnoma uresničila načela $\gg$ posebna umestitev javnih prostorov v skupnosti «, ker ni implementirala zelo pomembnega urbanističnega elementa - »skupnostno središče soseske «, in načela »javni prostor $\mathrm{v}$ središču «, zato ker nima osrednjega prostora za srečanja in druženje.

\section{Procesi urbanega eksperimentiranja}

Za namen analize lokalnega upravljanja se to poglavje osredotoča na urbano eksperimentiranje, kot ga opredeljujejo Bulkeley idr. (2015), in zajema procese » ustvarjanje, vzdrževanje« in » bivanje «. Proces » razširjanje informacij « je dodatna aktivnost pri raziskovanju (preglednica 2). Študija »procesov «, ki kaže dinamični razvoj soseske, je bistvena za raziskavo, saj 
Preglednica 1: Načela novega urbanizma (soseski Vauban in Western Harbour)

\begin{tabular}{|c|c|c|c|}
\hline $\begin{array}{l}\text { Načela novega } \\
\text { urbanizma }\end{array}$ & Definicija/glavni dejavniki & Vauban & Western Harbour \\
\hline \multirow{3}{*}{$\begin{array}{l}\text { 1. prijaznost soseske } \\
\text { do pešcev }\end{array}$} & večina trgovin, storitev oddaljenih 10 minut hoje od doma in službe & + & + \\
\hline & $\begin{array}{l}\text { pešcem prilagojeno načrtovanje ulic (stavbe v bližini ulic; terase, okna in vrata; uli- } \\
\text { ce, obdane z drevesi; parkiranje na ulici; skrita parkirna mesta; garaže v stranskem } \\
\text { pasu; ozke ulice za nizko hitrost avtomobilov) }\end{array}$ & + & + \\
\hline & včasih ulice samo za pešce & + & + \\
\hline \multirow{3}{*}{ 2. povezljivost } & povezana mreža ulic razprši promet in lajša hojo & + & + \\
\hline & hierarhija ozkih ulic, bulvarjev in alej & + & + \\
\hline & kakovosten sistem pločnikov in javnih površin omogoča prijetno hojo & + & + \\
\hline \multirow{2}{*}{$\begin{array}{l}\text { 3. večnamenska raba } \\
\text { in raznolikost }\end{array}$} & $\begin{array}{l}\text { mešanica trgovin, pisarn in stanovanj; mešana namenska raba na ravni soseske, } \\
\text { enote in stavb }\end{array}$ & + & + \\
\hline & raznolikost prebivalcev - glede na starost, dohodke, kulturo in raso & - & - \\
\hline 4. raznolika stanovanja & stanovanja različnih tipologij, velikosti, cen v neposredni bližini & + & + \\
\hline \multirow{3}{*}{$\begin{array}{l}\text { 5. kakovostna arhitek- } \\
\text { tura/urbana forma }\end{array}$} & poudarek na lepoti, estetiki, udobju in oblikovanju identitete prostora & + & + \\
\hline & posebna umestitev javnih prostorov $\mathrm{v}$ skupnosti & + & 0 \\
\hline & $\begin{array}{l}\text { arhitektura "po človeški meri« in privlačna okolica sta blagodejni za človekovo } \\
\text { dušo }\end{array}$ & + & + \\
\hline \multirow{4}{*}{$\begin{array}{l}\text { 6. tradicionalna } \\
\text { urbanistična struktura } \\
\text { soseske }\end{array}$} & prepoznavno središče in jasni robovi (meje) soseske & + & + \\
\hline & javni prostor v središču & + & 0 \\
\hline & $\begin{array}{l}\text { pomen kakovostnega javnega prostora; javni odprti prostor, zasnovan kot mestna } \\
\text { umetnost }\end{array}$ & + & + \\
\hline & $\begin{array}{l}\text { največja gostota mesta v središču (soseske) in postopno manjša gostota v smeri } \\
\text { proti robovom mesta (soseske) }\end{array}$ & + & + \\
\hline 7. večja gostota & $\begin{array}{l}\text { več stavb, bivališč, trgovin in storitev, ki so si blizu in dosegljive peš; to omogoča } \\
\text { učinkovitejšo uporabo storitev in ustvari bolj udoben, prijeten prostor za bivanje }\end{array}$ & + & + \\
\hline \multirow{2}{*}{ 8. zeleni prevoz } & udobni vlaki/tramvaji/avtobusi, ki povezujejo mesta in soseske & + & + \\
\hline & pešcem prijazna urbanistična zasnova, ki spodbuja hojo, uporabo koles in rolerjev & + & + \\
\hline \multirow{6}{*}{ 9. trajnost } & razvoj, ki stremi k čim manjšemu vplivu na okolje & + & + \\
\hline & okolju prijazne tehnologije, spoštovanje ekologije in pomena naravnih sistemov & + & + \\
\hline & energetska učinkovitost & + & + \\
\hline & manjša poraba goriva & + & + \\
\hline & več lokalne proizvodnje & & \\
\hline & več hoje, manj vožnje & & \\
\hline 10. kakovost življenja & $\begin{array}{l}\text { vsi dejavniki skupaj izboljšujejo kakovost življenja in ustvarjajo prostore, } \\
\text { ki bogatijo, poživljajo in izpolnjujejo človeškega duha }\end{array}$ & + & + \\
\hline
\end{tabular}

Vir: Avtor, 2016 
Preglednica 2: Procesi urbanega eksperimentiranja

\begin{tabular}{|c|c|}
\hline Procesi & Definicija \\
\hline \multirow{2}{*}{$\begin{array}{l}\text { ustvarjanje } \\
\text { (ang. making) }\end{array}$} & snovanje, oblikovanje in izvedba za izboljšanje urbanega okolja v povezavi s podnebnimi spremembami \\
\hline & $\begin{array}{l}\text { proces sestavljanja družbeno-tehničnih delov, elementov in deležnikov, ki tvorijo "prostor izjeme« in hkrati } \\
\text { "prostor inovacije» }\end{array}$ \\
\hline \multirow{2}{*}{$\begin{array}{l}\text { vzdrževanje } \\
\text { (ang. maintaining) }\end{array}$} & vzdrževanje eksperimentalnih lastnosti in izogibanje neustreznim elementom \\
\hline & $\begin{array}{l}\text { prilagajanje urbanemu snovnemu toku (metode, pri katerih je uporaba eksperimentov namenjena preobliko- } \\
\text { vanju oblike kroženja) }\end{array}$ \\
\hline \multirow{2}{*}{$\begin{array}{l}\text { bivanje } \\
\text { (ang. living) }\end{array}$} & $\begin{array}{l}\text { snovanje novih posameznih realnosti, skupaj s številnimi elementi, ki so sestavni del eksperimentov; ustvarja- } \\
\text { nje »eksperimentalnega subjekta« }\end{array}$ \\
\hline & $\begin{array}{l}\text { eksperimenti potekajo v negotovih razmerah (alternativne posamezne realnosti/razmerja so v procesu stalne- } \\
\text { ga pogajanja) }\end{array}$ \\
\hline \multirow{2}{*}{$\begin{array}{l}\text { ***razširjanje informacij } \\
\text { (ang. disseminating) }\end{array}$} & $\begin{array}{l}\text { izmenjava izkušenj z drugimi urbanimi območji in organizacijami; širjenje znanja in izkušenj na omrežja zunaj } \\
\text { lastnih meja; inkubatorji sprememb in prenos trajnostih rešitev v širše mestno okolje }\end{array}$ \\
\hline & $\begin{array}{l}\text { uvedba trajnostnega življenjskega sloga; prenos tehnoloških rešitev na sosednje (in oddaljene) soseske, mesta } \\
\text { in regije (trajnostna soseska kot primer dobre prakse) }\end{array}$ \\
\hline
\end{tabular}

Vir: Bulkeley idr., 2015 (priredil/razvrstil avtor, 2016)

»ustvarjanje« pojasnjuje začetni izvorni moment urbane regeneracije (začetno strategijo pristopa od zgoraj navzdol/od spodaj navzgor), ki je glavna neodvisna spremenljivka. Raziskava se osredotoča tudi na vpliv, ki ga ima implementacijski pristop (ustvarjanje) na nadaljnje procese.

\subsection{Ustvarjanje}

Za razumevanje kompleksnega sistema različnih akterjev oziroma urbanih komponent $\mathrm{v}$ soseskah Vauban in Western Harbour je treba najprej razumeti osnovne pogoje, zgodovino in razvojne procese teh specifičnih trajnostnih urbanih območij. $\mathrm{Na}$ začetku sta obe soseski poosebljali »prostore izjeme « v prevladujoči netrajnostni urbani praksi. Bili sta ekolaboratorija trajnostnega urbanizma (prostora inovacii), toda z drugačnima vizijama, strategijama načrtovanja in razvoja. Tudi sistem deležnikov, ki je določal urbanistično načrtovanje, je bil drugačen.

Leta 1993 je občina Freiburg pripravila urbanistični načrt za obnovo in spremembo nekdanje francoske vojašnice $\mathrm{v}$ sodobno trajnostno sosesko Vauban. Časovni okvir urbanističnega načrta se je ujemal z ustanovitvijo aktivistične organizacije SUSI, ki je zasedla zapuščeno vojašnico leta 1992. Organizacija SUSI in kasnejše združenje Forum Vauban sta bila glavna pobudnika za gradnjo avtonomne trajnostne soseske na območju Vauban. Povezana lokalna skupnost in dobra organizacija med prvotnimi prebivalci sta bili ključni za ustvarjanje dolgoročne (lokalne) identitete prostora in krepitev trajnostne usmerjenosti soseske. Občina Freiburg je priznala združenje Forum Vauban kot legitimnega partnerja in koordinacijski subjekt pri načrtovanju. Združenje je uvedlo več radikalnih postavk v urbanističnem načrtu soseske in doseglo denimo »prepoved avtomobilov « v njej, da bi se lahko otroci varno igrali na ulicah (Field, 2011). Tudi energetski koncept soseske je bil izdelan v sodelovanju občine Freiburg, združenja Forum Vauban in energetskega podjetja iz mesta Freiburg (Bächtold, 2013). Pri razvoju trajnostne soseske je Forum Vauban podpiral različne neprofitne organizacije, recimo gradbene zadruge, ter dal pobudo za sodelovanje na energetskem in prehrambnem področju. Soseska Vauban uteleša radikalno ekocentrično tranzicijsko verzijo, ki promovira lokalni pristop od spodaj navzgor z namenom pospeševanja družbenih, okoljskih in kulturnih sprememb (Audet, 2014).

Območje Western Harbour je bilo v lasti občine Malmö, ki je želela spremeniti ta industrijski predel po stečaju več podjetij (Lööf, 2014). Namen preoblikovanja je bil ustvariti vzoren primer trajnostnega urbanega razvoja ter okrepiti novo podobo Malmöja kot idealnega mesta za bivanje in naložbe (Madureira, 2014). Pobudniki trajnostne soseske Western Harbour niso bili lokalni prebivalci, ki so živeli in delali na tem območju, ampak državne institucije (občina Malmö). Javnost je imela malo vpliva na urbanistični načrt območja Western Harbour tudi zato, ker so bili že na začetku vključevanja javnosti arhitekturni načrti podrobno zastavljeni (Lööf, 2014).

Ena temeljnih razlik med soseskama Vauban in Western Harbour glede začetnega nastajanja je bila v ravni vključenosti lokalnih prebivalcev pri ustvarjanju koncepta razvoja trajnostne soseske. Vizija Foruma Vauban »učiti se med načrtovanjem « (ang. learning while planning) je bila tipičen primer participatornega pristopa od spodaj navzgor. Čeprav je občina Freiburg omogočila nastanek trajnostne soseske oziroma bistveno pripomogla $\mathrm{k}$ temu, so imeli veliko večji vpliv na trajnostni urbani razvoj lokalni prebivalci prek gradbenih zadrug (nem. 
Baugruppen). Lokalni prebivalci so postavljali višje okoljske standarde, izbirali arhitekte, usmerjali načrtovanje in vodili gradnjo. V nasprotju s tem pa je občina Malmö samostojno upravljala razvoj soseske Western Harbour: vodila arhitekte in gradbena podjetja. Pri soseski Western Harbour, kot tipični predstavnici pristopa od zgoraj navzdol je cilje določila mestna uprava. Kritiki opozarjajo, da pri »ustvarjanju « lokalne transformacije v soseski Western Harbor ni bilo (zadostnega) sodelovanja s civilno družbo.

\subsection{Vzdrževanje}

»Vzdrževanje « se nanaša na dve različni, vendar povezani obliki vzdrževanja urbanih eksperimentov (Bulkeley idr., 2015). Bulkeley idr. (2015) so določili dve tipologiji vzdrževanja: ohranitev in presnovna prilagoditev. Ohranitev je bolj fizična in neposredna. Gre za vsakdanje ukrepe (odstranjevanje odpadkov, pleskanje itd.), kombinirane z nekaterimi bolj strateškimi posegi (vlaganje v energetsko prenovo, urejanje cestnega prometa itd.). Pri presnovni prilagoditvi pa gre za metode, pri katerih je uporaba eksperimentov namenjena preoblikovanju trenutne oblike kroženja (Bulkeley idr., 2015). Presnovna prilagoditev se kaže v prilagoditvah občinske politike, pri tehnološkem razvoju in razvoju novih kulturnih kompetenc ter je lahko usmerjena tudi v prilagoditev novih urbanih kontekstov.

Analiza se osredotoča na to, kako konkretni »eksperimenti intervenirajo, da bi preoblikovali cirkulacijo omrežja s presnovno prilagoditvijo « (Bulkeley idr, 2015: 39). Pri presnovni prilagoditvi soseske Vauban je treba upoštevati dva vala prilagoditev in modifikacij. Prvi je povezan z energetskimi standardi gradbenih zadrug. Združenje Forum Vauban je bilo še posebej uspešno pri spodbujanju samostojnih gradbenikov, da so sprejeli strožje in radikalnejše obvezne ekološke standarde. Očitno standard energetske učinkovitosti $65 \mathrm{kWh} / \mathrm{m}^{2} /$ leto, ki ga je določila občina Freiburg, ni bil dovolj stimulativen, zato je združenje spodbudilo neformalno tekmovanje med gradbenimi zadrugami, da bi še dodatno zmanjšali porabo energije v novih stavbah (Delleske, 2013). Omogočilo je brezplačno svetovanje ter organiziralo številne prireditve in seminarje za pomoč ter informiranje lokalnih zadrug glede tehnoloških rešitev za energetsko varčevanje (Bächtold, 2013). Številni člani gradbenih zadrug so določili lastne, še strožje standarde. Druga » presnovna prilagoditev « soseske Vauban se navezuje na družbeno strukturo lokalnega prebivalstva. $V$ preteklih letih se je ta nekoliko spremenila. Od radikalnega zelenega aktivizma prvih pionirjev se soseska Vauban počasi, toda vztrajno spreminja v sosesko za družine, ne da bi izgubila svoj unikatni trajnostni pečat. Poleg tega je treba omeniti, da je pobudnica soseske - aktivistična skupina SUSI še vedno del soseske in ima pomembno vlogo v lokalni skupnosti, saj ponuja ugodna socialna najemna stanovanja. Kljub temu je težnja k gentrifikaciji prostora očitna.

Tudi soseska Western Harbour se je pri urbani transformaciji večkrat prilagajala novim razmeram $s$ posebnimi prilagoditvami. Na začetku trajnostne urbane preobrazbe je imela negativno javno podobo in bila pogosto tarča kritik v medijih. Ograjeni park, obvezno plačilo vstopnic za razstavo EXPO za prebivalce mesta Malmö, ki je privedlo do bojkota dogodka, finančni škandali gradbenih podjetij, neplačila lokalnim podjetjem in stečaj glavnega razvojnega podjetja so samo nekatere od negativnih okoliščin, ki so spremljale začetek transformacije soseske Western Harbour (Dalman, 2014; Lööf, 2014). Lokalni kritiki in mediji so opozorili tudi na visoke cene stanovanj in s tem »getoizacijo « območja (Holgersen, 2014). Kljub temu je v zadnjih letih soseska postala zelo zaželeno območje za bivanje ter hkrati tudi osrednji rekreacijski in zabaviščni prostor mesta Malmö, pa tudi turistična atrakcija. Vzdrževanje oziroma prilagajanje se kaže tudi v tem, kako se je soseska odzvala na svojo novo vlogo. Ponuja na primer posebne storitve, kot so bari, restavracije itd., za nove/nepričakovane obiskovalce soseske. Vendar nekateri prebivalci niso bili navdušeni nad to novo odprtostjo za zunanje obiskovalce in bi rajši ohranili bolj zaprto lokalno skupnost (Dalman, 2014). Drugi vidik rekonfiguracije med eksperimentiranjem se kaže v odzivu občine Malmö glede nenatančnih napovedi o energetski učinkovitosti stavb (Bächtold, 2013). Na nepričakovane okoliščine se je odzvala z različnimi ukrepi, ki naj bi spremenili in izboljšali razumevanje ter zavezanost stanovalcev $\mathrm{k}$ zastavljenim ciljem trajnostnega razvoja (Johansson, 2014).

\subsection{Bivanje}

Bivanje vključuje različne nove partikularne realnosti, ki skupaj ustvarjajo tako imenovani eksperimentalni subjekt (Bulkeley idr., 2015). Obe soseski sta primer eksperimentalnega bivanjskega laboratorija, vendar z drugačnima sistemoma lokalnega upravljanja ter različnimi deležniki in odločevalci. V soseski Western Harbour je glavni deležnik in odločevalec občina Malmö, ki upravlja sosesko s svojimi javnimi zavodi in sodelovanjem nekaterih zasebnih podjetij (npr: E.ON). Zasebna podjetja opravljajo različne tehnične poskuse v zvezi z okoljskimi rešitvami, apliciranimi v nizkoenergijskih stanovanjih, z električnimi omrežji za obnovljive vire energije itd. V nasprotju z obravnavano švedsko sosesko pa je soseska Vauban s svojima participativnima lokalnima združenjima Forum Vauban in SUSI in različnimi gradbenimi zadrugami, kooperativami obnovljivih virov energije in lokalnimi društvi v soseski ustvarila množico prepletenih deležnikov, ki tvorijo edinstven sistem lokalnega upravljanja (slika 5). Sistem lokalnega upravljanja v soseski Vauban prepušča pobudo lokalnim prebivalcem. 


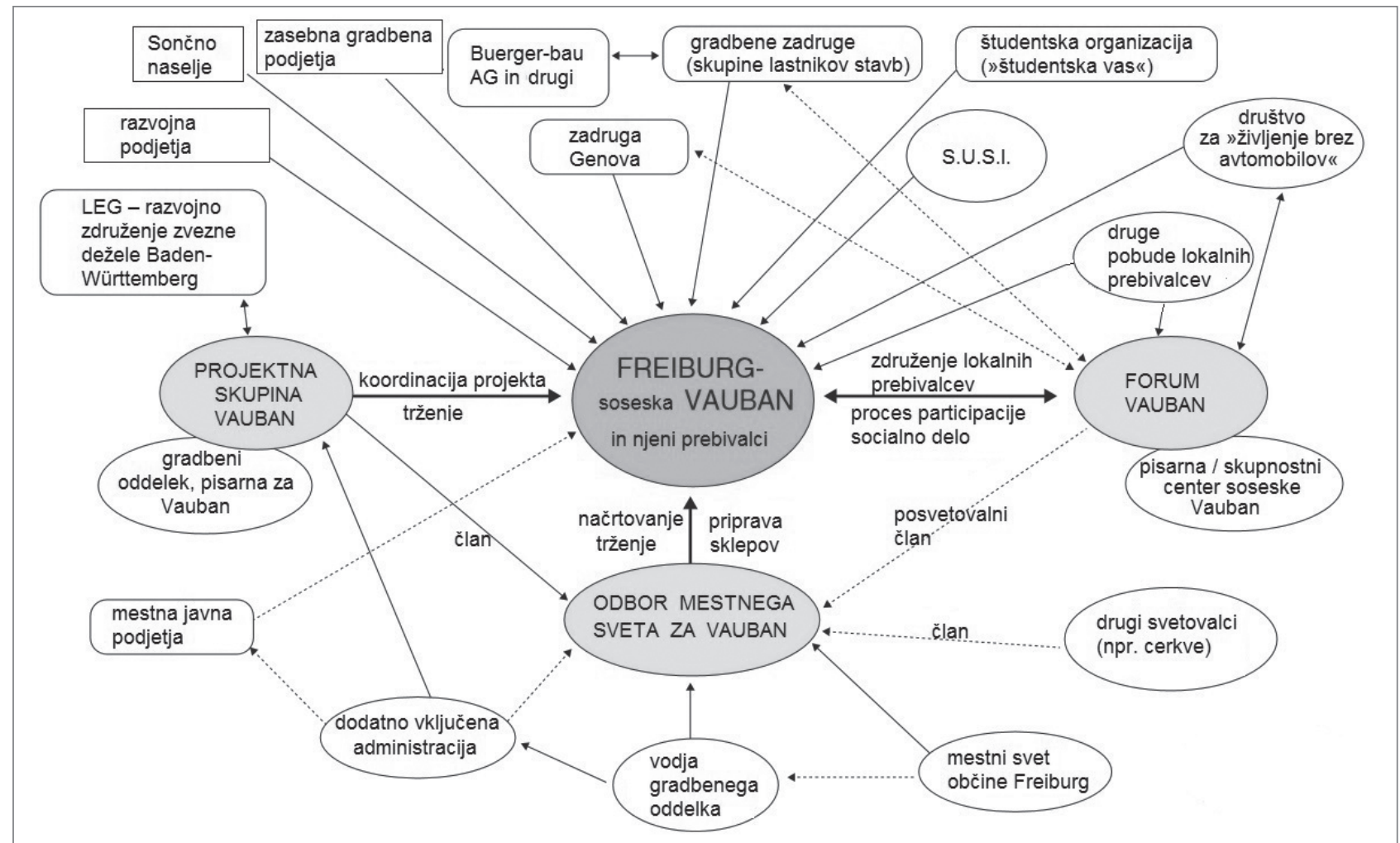

Slika 5: Sistem lokalnega upravljanja v trajnostni soseski Vauban (vir: internet 2)

Bulkeley idr. (2015) trdijo, da eksperimenti delujejo na negotovih področjih in so podvrženi stalnim pogajanjem. V soseski Vauban je združenje Forum Vauban doživelo stečaj, ko je EU nepričakovano prenehala financirati njene dejavnosti, vendar se je združenje preoblikovalo in spet postavilo na noge z novim imenom Stadtteilverein Vauban (Delleske, 2013). Stalna pogajanja in vnovično prilagajanje notranjih pravil lokalnega »bivanjskega « eksperimenta so zaznamovala tudi sosesko Western Harbour. Zaradi razmeroma homogene socialne strukture prebivalstva v predelu Bo01 je občina Malmö sklenila z gradbenimi podjetji posebno »socialno pogodbo « za nadaljnje urbane projekte v soseski (Bo02, Bo03). Ni namreč želela, da bi postal Western Harbour »zlata obala mesta Malmö « (Dalman, 2014). Zato je po prvem zgrajenem urbanem območju (Bo01) nameravala zagotoviti večjo vključenost ljudi v projektih Bo02 in Bo03. Mesto Malmö je nameravalo zgraditi najcenejša najemna stanovanja $\mathrm{v}$ mestu, zato je subvencioniralo zemljišča $\mathrm{v}$ nekaterih delih območja Bo02. V zameno so gradbena podjetja podpisala sporazum, da ne bodo zaračunavala višje najemnine od najnižjega kvartila povprečne najemnine v mestu Malmö. Na koncu se je izkazalo, da najemnine niso ostale dolgo tako nizke (Dalman, 2014). Kot je bilo že omenjeno, je soseska Western Harbour (Bo01) doživela veliko kritik na začetku obstoja (zlasti v medijih). Kljub tej stigmi velja eksperiment Western Harbour za svetovno priznano zgodbo o uspehu in model dobre prakse. Ustvarjanje novih oblik urbanih eksperimentov ustvarja nova pričakovanja o tem, kaj je (in ni) normalno (Bulkeley idr., 2015).

\subsection{Razširjanje informacij}

Soseski Vauban in Western Harbour sta trajnostni soseski s celostnim pristopom do vzdržnega urbanega razvoja. Zato se mnoga mesta po svetu želijo učiti od njiju. Inovativni proces »razširjanje informacij « je pomemben pri razvoju trajnostnih sosesk, ker predvideva izmenjavo izkušenj z drugimi urbanimi območji in organizacijami. Obe soseski sta neposredno in posredno razširili svoji mreži onstran svojih meja. Seveda je težko izmeriti in opredeliti, koliko sta svojimi urbanimi trajnostnimi pristopi vplivali na druge dele lastnega mesta, regije in države in koliko na mednarodni ravni. V nadaljevanju so predstavljeni nekateri konkretni ukrepi, vplivi, znanje in izkušnje, ki sta jih obe soseski širili onstran svojih meja.

Ta proces v soseski Vauban je mogoče povzeti v štirih točkah. Prvič, specifično znanje strateškega upravljanja in druge organizacijske rešitve so bile prenesene na druge dele mesta Freiburg (denimo Rieselfeld) in v druga mesta v regiji (recimo Französisches Viertel-Südstadt v Tübingenu). Poseben energetski standard v soseski Vauban je bil navdih standardu za energetsko učinkovitost stavb v soseski Rieselfeld. Oba standarda sta bila podlaga za standard, ki je začel veljati leta 2009 za 
mesto Freiburg (Bächtold, 2013). Drugič, implementacija prve plusenergijske večdružinske stavbe na svetu pomeni tehnično rešitev, ki so jo urbanisti in arhitekti intenzivno analizirali. Tretjič, vodeni ogledi soseske Vauban za turiste in raziskovalce, ki so jih organizirali lokalni prebivalci, so učinkovit način širjenja specifičnih izkušenj trajnostnega urbanizma. Tudi informativni seminarji o razvojnem procesu v soseski Vauban omogočajo širjenje znanja. Četrtič, trajnostni živi laboratorij prva pasivna večstanovanjska stavba (Passivhaus Wohnen und Arbeiten), ki ga je mogoče obiskati tudi z vodenimi ogledi, neposredno predstavlja konkretne trajnostne rešitve, uporabljene v soseski.

V soseski Western Harbour je možno proces opredeliti s tremi aktivnostmi. Prvič, znanje o strategijah upravljanja in drugih organizacijskih rešitvah je bilo preneseno na druge dele mesta Malmö - denimo Hyllie in Augustenborg in druga mesta v regiji - novi planski načrti za trajnostno sosesko v mestu Lund (Dalman, 2014). Podobno kot pri soseski Vauban so bili trajnostni standardi za objekte, zgrajene za Bo01 (Western Harbour), kasneje podlaga za poseben program, ki je veljal za vse stavbe na občinskih zemljiščih mest Malmö in Lund (Smedby, 2016). Posebno socialno pogodbo med gradbenimi podjetji in občino Malmö je prevzela tudi občina Kopenhagen (Lööf, 2014). Strategija storitve souporaba avtomobilov s posebno pogodbo, sklenjeno med občino, gradbeniki in podjetji, je bila prenesena tudi na druge soseske $\mathrm{v}$ mestu Malmö, na primer Hyllie (Lööf, 2014). Sistem prometa v soseski Western Harbour pa je postal model za vse mesto Malmö (Fraker, 2013). Drugič, z vidika aplikacije tehničnih rešitev je bil izboljšan sistem za odpadke (razvit v soseski Western Harbour v Bo01) ponovno uporabljen v Bo03 in bo postal model za celotno mesto (Dalman, 2014; Lööf, 2014). Tretjič, vodene oglede soseske Western Harbour so organizirali za tisoče mednarodnih obiskovalcev.

\section{Sklep}

Izhajajoč iz analize načel novega urbanizma, je mogoče sklepati, da je soseska Vauban s pristopom od spodaj navzgor dosegla lokalni skupnosti prilagojeno urbanistično formo, podobno kot soseska Western Harbour s pristopom od zgoraj navzdol. Začetni pristop implementacije (od zgoraj navzdol ali od spodaj navzgor) ni vplival na trajnostno obliko urbane forme v proučevanih primerih. $V$ obeh soseskah so bila uresničena skoraj vsa načela novega urbanizma. Treba pa je poudariti, da ni bil dosežen temeljni vidik novega urbanizma - raznolikost oziroma heterogenost lokalnega prebivalstva soseske. Po analizi načel novega urbanizma v obravnavanih soseskah je prva hipoteza zavrnjena. To pomeni, da trajnostne soseske s pristopom od spodaj navzgor ne ustvarjajo bolj trajnostne urbane forme, saj je tudi urbanistična forma soseske Western Harbour, nastala s pristopom od zgoraj navzdol, skladna z načeli novega urbanizma. Tudi druge evropske trajnostne soseske, nastale $s$ pristopom od zgoraj navzdol (Kronsberg v Hannovru, Hammarsby Sjöstad v Stockholmu itd.), imajo zelo funkcionalno in trajnostno urbano strukturo, ki spodbuja hojo, ter veliko gostoto naseljenosti, vključujejo večnamenske objekte, so dobro povezane z zelenim mestnim prevozom, imajo veliko parkov, omogočajo (javne) storitve v bližini stanovanjskih območij itd. (Fraker, 2013). Zato je mogoče sklepati, da je večina načel novega urbanizma v trajnostnih soseskah uresničljiva ne glede na začetni implementacijski pristop.

Za razliko od prve hipoteze je na podlagi primerjalne analize mogoče potrditi drugo hipotezo: trajnostne soseske, implementirane s participativnim pristopom od spodaj navzgor, ustvarjajo kompleksnejšs sisteme lokalnega upravljanja in so socialno vzdržnejše. $Z$ analizo na podlagi teoretičnega okvira procesov je mogoče potrditi, da je začetni implementacijski pristop (od spodaj navzgor in od zgoraj navzdol) odločilen pri določanju, kdo (združenja lokalnih prebivalcev ali občina) bo glavni deležnik, protagonist, odločevalec, ki se bo odzival na vsakodnevne izzive soseske. $\mathrm{Z}$ analitičnim okvirom procesov je bilo ugotovljeno, da je v obeh študijah primerov začetni razvojni proces »ustvarjanje « neposredno vplival na nadaljnje procese ter definiral končni sistem lokalnega upravljanja in socialno strukturo skupnosti. Prebivalci soseske Vauban so glavni deležniki pri odločanju. $\mathrm{V}$ gradbenih zadrugah in združenju Forum Vauban določajo socialne, gospodarske in okoljske cilje za sosesko. V nasprotju s tem pa je sosesko Western Harbour načrtovala, gradila in razvijala občina Malmö. Z analizo procesov » vzdrževanje « in » bivanje « je bilo ugotovljeno, da se glavni deležniki - skrbniki oziroma administratorji sosesk - skozi čas niso ključno spremenili oziroma zamenjali.

Analiza procesov je tudi pokazala, da je pristop od spodaj navzgor v soseski Vauban spodbudil bolj družbeno usmerjene trajnostne organizacije in dejavnosti $\mathrm{k}$ temu, da lokalne skupnosti izrazijo svojo vitalnost. Podobno so tudi druge evropske soseske, nastale s participativnim pristopom od spodaj navzgor (denimo soseska GWL Terrein iz Amsterdama in EVA Lanxmeer iz Culemborga), razvile močno identiteto lokalnega urbanega prostora in socialno kohezijo ter pooblastile lokalne prebivalce, da so prevzeli odgovornost pri več dejavnostih soseske. Zato bi bilo v prihodnje za razvoj socialno vzdržnih mestnih območij z močnim lokalnim upravljanjem, usmerjenim v korist lokalne skupnosti, dobro že na začetku (proces »ustvarjanja «) uvesti pri načrtovanju participativni dialog in vključiti lokalno skupnost pri razvoju urbane strategije.

Kljub ugotovljenim razlikam med obema soseskama pri procesih »ustvarjanje«, »vzdrževanje « in »bivanje « je veliko 
podobnosti pri procesu »razširjanje informacij «. Med obema proučevanima soseskama ni bistvenih razlik pri prenosu oziroma deljenju znanja. Obe uspešno prenašata naprej pridobljeno tehnično znanje in izkušnje (standardi energetske učinkovitosti, bivanjski laboratoriji, sistem predelave odpadkov itd.) ter širita svoje strategije upravljanja in druge organizacijske rešitve (koncept »družbene pogodbe « z gradbenimi podjetji, sistem souporabe avtomobilov, vodeni izleti po soseskah itd.) $\mathrm{v}$ druge urbane skupnosti.

Obravnavani študiji primerov omogočata edinstven vpogled $\mathrm{v}$ načela in procese oblikovanja trajnostnih sosesk. Univerzalne rešitve ali načrta, ki bi ga bilo mogoče aplicirati pri nastajanju in razvoju novih trajnostnih sosesk, ni. Obe soseski sta mednarodno priznana modela urbanega trajnostnega razvoja ter navdih mestom in organizacijam po vsem svetu. Poosebljata primere različnih načel in procesov, ki vodijo do podobnega cilja - trajnostnih sosesk.

Primož Medved

Ljubljana, Slovenija

E-pošta: primozmedved@yahoo.com

\section{Viri in literatura}

Audet, R. (2014): The double hermeneutic of sustainability transitions. Environmental Innovation and Societal Transitions 11, str. 46-49. DOI: 10.1016/j.eist.2014.02.001

Bächtold, P. (2013): The space-economic transformation of the city. Heidelberg, Springer. DOI: 10.1007/978-94-007-5252-8

Banister, D. (2005): Unsustainable transport: City transport in the new century. Abington, Routledge.

Barton, H., Grant, M., in Guise, R. (2003): Shaping neighbourhoods: A guide for health, sustainability and vitality. New York, Spon Press.

Bayulken, B., in Huisingh D. (2015): Are lessons from eco-towns helping planners make more effective progress in transforming cities into sustainable urban systems: a literature review (part 2 of 2). Journal of Cleaner Production 109, str. 152-165. DOI: 10.1016/j.jclepro.2014.12.099

Bratina Jurkovič, N. (2014): Perception, experience and the use of public urban spaces by residents of urban neighbourhoods. Urbani izziv, 25(1), str. 107-125. DOI: 10.5379/urbani-izziv-en-2014-25-01-003

Bulkeley, H., Castán Broto, V., in Edwards, G. (2015): An urban politics of climate change. London, Routledge.

Churchill, C., in Baetz, B. (1999): Development of decision support system for sustainable community design. ASCE Journal of Urban Planning and Development, 125, str. 17-35.

DOI: 10.1061/(ASCE)0733-9488(1999)125:1(17)

CNU in HUD (2000): Principles for inner city neighborhood design. The Congress of New Urbanism, HOPE VI project.

Dalman, E. (2014): Pogovor o razvoju in značilnostih trajnostne soseske Western Harbour (osebni vir, 13. 5. 2014).

Daseking, W. (2013) Pogovor o razvoju in značilnostih trajnostni sosedske Vauban (osebni vir, 7. 4. 2013).

Delleske, A. (2013): Pogovor o razvoju in značilnostih trajnostni sosedske Vauban (osebni vir, 6. 4. 2013).
Fainstein, S. S. (2010): The just city. Ithaca, Cornell University Press.

Ferreira da Cruz, N., in Marques, R. (2014): Scorecards for sustainable local governments. Cities, 39, str. 165-170.

DOI: 10.1016/j.cities.2014.01.001

Field, S. (2011): Case study: Vauban. V: Foletta, N., in Field, S. (ur.): Europe's Vibrant New Low Car(bon) Communities, str. 94-106. New York, IDTP.

Flyvbjerg, B. (2006): Five misunderstandings about case-study research. Qualitative Inquiry, 12(2), 219-245. DOI: 10.1177/1077800405284363

Foletta, N. (2011): Case study: Västra Hamnen. V: Foletta, N. in Field, S. (ur.): Europe's Vibrant New Low Car(bon) Communities, str. 82-93. New York, IDTP.

Forrest, N., in Wiek, A. (2014): Learning from success - Toward evidence-informed sustainability transitions in communities. Environmental Innovation and Societal Transitions, 12, str. 66-88.

DOI: 10.1016/j.eist.2014.01.003

Fraker, H. (2013): The hidden potential of sustainable neighborhoods. Washington, Island Press.

Frey, H. (1999): Designing the city: Towards a more sustainable urban form. London, Spon. DOI: 10.4324/9780203362433

Gaventa, J., in Valderrama, C. (1999): Participation, citizenship and local governance. Prispevek je bil predstavljen na konferenci z naslovom Strengthening Participation in Local Governance, ki je potekala od 21. do 24. junija v Brightonu. Tipkopis.

Gombert, S. (2013): Pogovor o razvoju in značilnostih trajnostni sosedske Vauban (osebni vir, 7. 4. 2013).

Grant, J. (2006): Planning the good community: New urbanism in theory and practice. London, Royal Town Planning Institute Library Series, Routledge.

Harvey, D. (1990): The Condition of postmodernity. Cambridge, Blackwell.

Holgersen, S. (2014): The rise (and fall?) of post-industrial Malmö investigations of city-crisis dialectics. Lund, Lund University.

Internet 1: http://www.newurbanism.org/newurbanism/principles.html (sneto 20. 5. 2016).

Internet 2: https://www.oeko.de/ (sneto 18. 5. 2016).

Internet 3: http://www.passivhaus-vauban.de/ (sneto 20. 5. 2016).

Johansson, J. (2014): Pogovor o razvoju in značilnostih trajnostne soseske Western Harbour (osebni vir, 20. 5. 2014).

Kärrholm, M. (2011): The scaling of sustainable urban form: A case of scale-related issues and sustainable planning in Malmö, Sweden. European Planning Studies, 19 (1), str. 97-112.

DOI: 10.1080/09654313.2011.530394

Kushner, J. A. (2002): Smart growth, new urbanism and diversity: Progressive planning movements in America and their impact on poor and minority ethnic populations. UCLA Journal of Environmental Law and Policy, 21(1), str. 45-74.

Kyvelou, S., Sinou, M., Baer, I., in Papadopoulos, T. (2012): Developing a South-European eco-quarter design and assessment tool based on the concept of territorial capital. V: Curkovic, S. (ur.): Sustainable development - Authoritative and leading edge content for environmental management, str. 561-588. Rijeka, Intech. DOI: 10.5772/45885

Lööf, M. (2014): Pogovor o razvoju in značilnostih trajnostne soseske Western Harbour (osebni vir, 9. 5. 2014).

Madureira, A. M. (2014): Physical planning in entrepreneurial urban governance - Experiences from the Bo01 and Brunnshög Projects, Sweden. European Planning Studies, 22(11), str. 2369-2388. DOI: 10.1080/09654313.2013.843650 
Madureira A. M. (2015): Physical planning in place-making through design and image building. Journal of Housing and the Built Environment, 30(1), str. 157-172. DOI: 10.1007/s10901-013-9381-2

Medved, P. (2016): A contribution to the structural model of autonomous sustainable neighbourhoods: new socio-economical basis for sustainable urban planning. Journal of cleaner production, 120, str. 21-30. DOI: 10.1016/j.jclepro.2016.01.091

Rahnama, M. R., Roshani, P., Hassani, A. in Hossienpour, S.A. (2012): Use principles of new urbanism approach in designing sustainable urban spaces. International Journal of Applied Science \& Technology, 2(7), str. 195-203.

Rogatka, K., in Ramos Ribeiro, R., R. (2015): A compact city and its social perception: A case study. Urbani izziv, 26(1), str. 56-66.

DOI: 10.5379/urbani-izziv-2015-26-01-005

Rudlin, D., in Falk, N. (2009): Sustainable urban neighbourhood: Building the $21^{\text {st }}$ century home. Oxford, Architectural Press.

Sperling, C. (2002): Sustainable urban district Freiburg - Vauban. Dostopno na: http://www.carstensperling.de/pdf/dubai-submission.pdf (sneto 8. 6. 2016).

Sperling, C. (2008): Freiburg - Vauban; From military area to model district: Sustainable neighbourhood design - A communicative process. Newcastle: CABE Urban Design Summer School. Dostopno na: http:// webarchive.nationalarchives.gov.uk/20110118095356/http:/www.cabe. org.uk/files/udss2008-carstensperling.pdf (sneto 10. 6. 2016).

Smedby, N. (2016): Assessing local governance experiments for building energy efficiency - the case of Malmö, Sweden. Environment and Planning C: Government and Policy, 34, str. 299-319. DOI: $10.1177 / 0263774 X 15614176$

World Bank (2013): Passenger cars (per 1,000 people). Dostopno na: http://data.worldbank.org/indicator/IS.VEH.PCAR.P3 (sneto 8. 6. 2016).

Zinkernagel, R. (2014): Pogovor o razvoju in značilnostih trajnostne soseske Western Harbour (osebni vir, 9. 5. 2014). 